\title{
The splenic Littoral cell angioma in China: a case report and review
}

\author{
Zong-Qiang $\mathrm{Hu}^{1}$, Yong-Jun A', Qiang-Ming Sun ${ }^{2}$, Wen $\mathrm{Li}^{1}$ and $\mathrm{Li} \mathrm{Li}^{3^{*}}$
}

\begin{abstract}
Littoral cell angioma (LCA) is a rare splenic vascular neoplasm that arises from the cells lining the red pulp sinuses. It is deemed to be a benign and incidental lesion. The earliest literature report of littoral cell angioma has been described by Falk. The examination of samples after splenectomy reveals similar pathological change and its change rule is summarized. However, many recent reports have described it to be a malignant tumor with congenital and immunological associations. Generally speaking, the definitive diagnosis can only be made after histological and immunohistochemical profiles. In this case report, we presented the case of a 48-year-old woman with multiple splenic LCAs. Initially, the patient was characteristics of abdominal distension, weakness and fatigue. Multiple hemangiomas were observed in the spleen through abdominal ultrasonic diagnosis. Computed tomography (CT) scans revealed the splenomegaly with multiple round and hyperdense lesions. The patient subsequently underwent splenectomy. Postoperative histological and immunohistochemical studies confirmed the diagnosis of LCA. Based on the presentation of this case, clinical, radiographic and pathological results of LCA as well as recent advances in our understanding of this uncommon splenic lesion were reviewed. LCA is an uncommon splenic tumor diagnosed in patients with or without abdominal discomfort. Only a few case reports regarding this kind of tumor have been published as inconsistent results. In the present paper, we have reported a case of LCA and reviewed the literature.
\end{abstract}

Keywords: littoral cell angioma, vascular neoplasm, histology and immunohistochemistry, surgery

\section{Background}

LCA is a benign neoplasm of the spleen that was first described by Falk et al. in 1991 [1,2], when they illustrated 17 cases of "a novel type of vascular tumor" [3]. Since then, no more than 80 additional cases have been reported $[4,5]$. The clinical representation of LCA ranges from being completely asymptomatic and discovered incidentally, to presenting with aconstellation of signs and symptoms such as abdominal distension, complex constitutional symptoms, splenomegaly, and hypersplenism [6,7]. Although the computed tomography (CT) and ultrasound (US) features of this neoplasm have been well described, there is a lack of specificity in differentiating the tumor from other primary vascular splenic tumors, namely, hemangiomas and angiosarcomas [8-10]. The definitive diagnosis can only be made after

\footnotetext{
* Correspondence: ynkmlili@yahoo.com.cn

${ }^{3}$ Ganmei Affiliated Hospital of Kunming Medical University, Kunming 650011, China

Full list of author information is available at the end of the article
}

histological and immunohistochemical studies [11]. Since this is initial description, there only have scattered case reports and few case series of LCA. In this article, we would like to report a case of the rare splenic vascular neoplasm.

\section{Case report}

A 48-year-old Chinese woman was admitted due to non-specific complaints of abdominal distension, weakness and fatigue. This patient had been diagnosed with an oophoritic cyst 11 years ago and right oophorocystectomy. Meanwhile, this patient did not have medical history of weight loss, fever, or changes in bowel habits. Physical examination was notable for only splenomegaly. Abdominal ultrasonographic examination showed the increase in volume and multifocal processes throughout the spleen (Figure 1). CT scans confirmed the splenomegaly with multiple round and hyperdense lesions in the spleen. Contrast enhancement revealed an early hypoattenuation on arterial and most early portal phase
C Biomed Central

() 2011 Hu et al; licensee BioMed Central Ltd. This is an Open Access article distributed under the terms of the Creative Commons Attribution License (http://creativecommons.org/licenses/by/2.0), which permits unrestricted use, distribution, and reproduction in any medium, provided the original work is properly cited. 


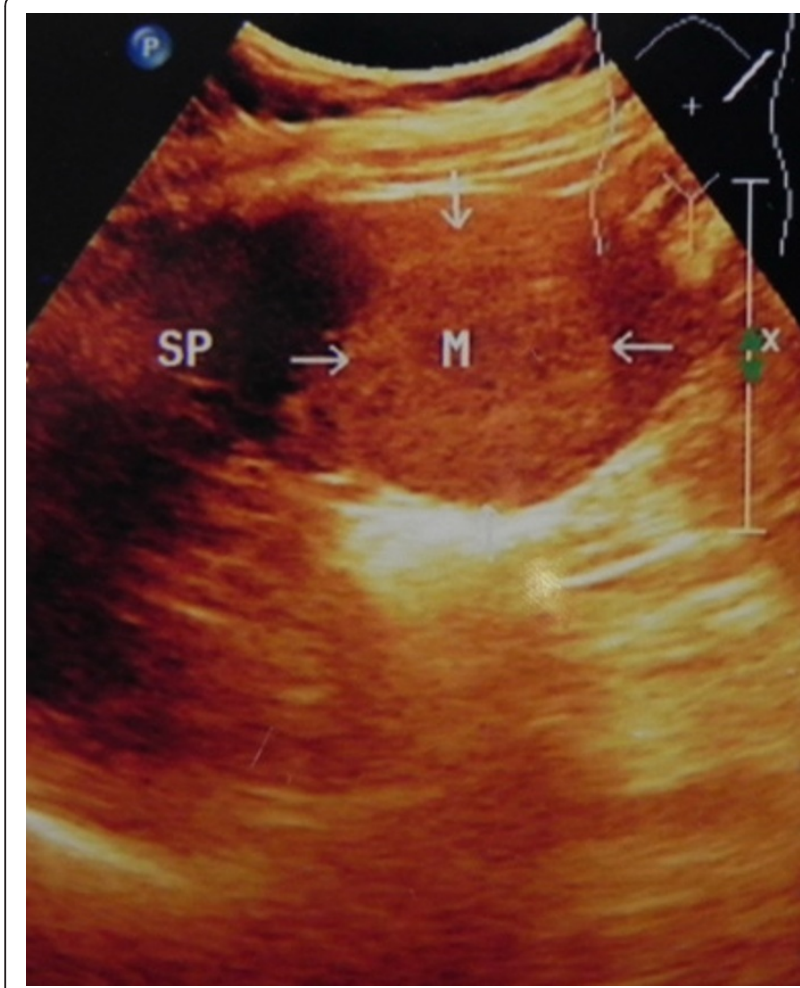

Figure 1 Ultrasound of the spleen. Ultrasound of the spleen demonstrates a well-defined hyperechoic lesion.

scans. There was heterogeneous to homogeneous enhancement on late portal phase and delayed images. Some delayed scans have described a complete contrast washout with return to isoattenuation. In general, the
CT can show an isoattenuated mass within the superior aspect of the spleen, which is barely perceptible on the noncontrast examination. The results from laboratory examinations were normal and the serologic examination for hepatitis A, B and C was negative. Our preoperative diagnosis was hemangioma. Subsequently, the patient underwent splenectomy. Post-operative rough pathological examination revealed a moderately enlarged spleen with approximately $1020 \mathrm{~g}$ in weight and $18 \times 10$ $\times 6 \mathrm{~cm}$ in dimensions. The capsular surface of the spleen showed multifocal sponge-like vascular spaces (Figure 2). The nodules with dark bluish red, smooth and multilobulated surface were ranged from 0.3 to 4.4 $\mathrm{cm}$. In addition, these nodules were characterized as having multiple cystic spaces and structures resembling exaggerated red pulp sinusoids [12-14]. Histologically, this lesion was described as a vascular neoplasm with anastomosing vascular channels lined by histiocytes with occasional papillary structures, which was consistent with LCA (Figure 3). Immunohistochemistry was positive for factors CD31 and CD68 and negative for CD34 and CD21, thus confirming the diagnosis of LCA, and mitigating the diagnosis of angiosarcoma. The patient's post-operative course was uneventful, and her general condition was improved markedly within 100 days after the operation.

\section{Discussion}

The differential diagnosis of splenic vascular tumors are broad and may represent benign (haemangioma, haemartoma and lymphangioma), indeterminate (LCA, haemangioendothelioma and haemangiopericytoma), or malignant

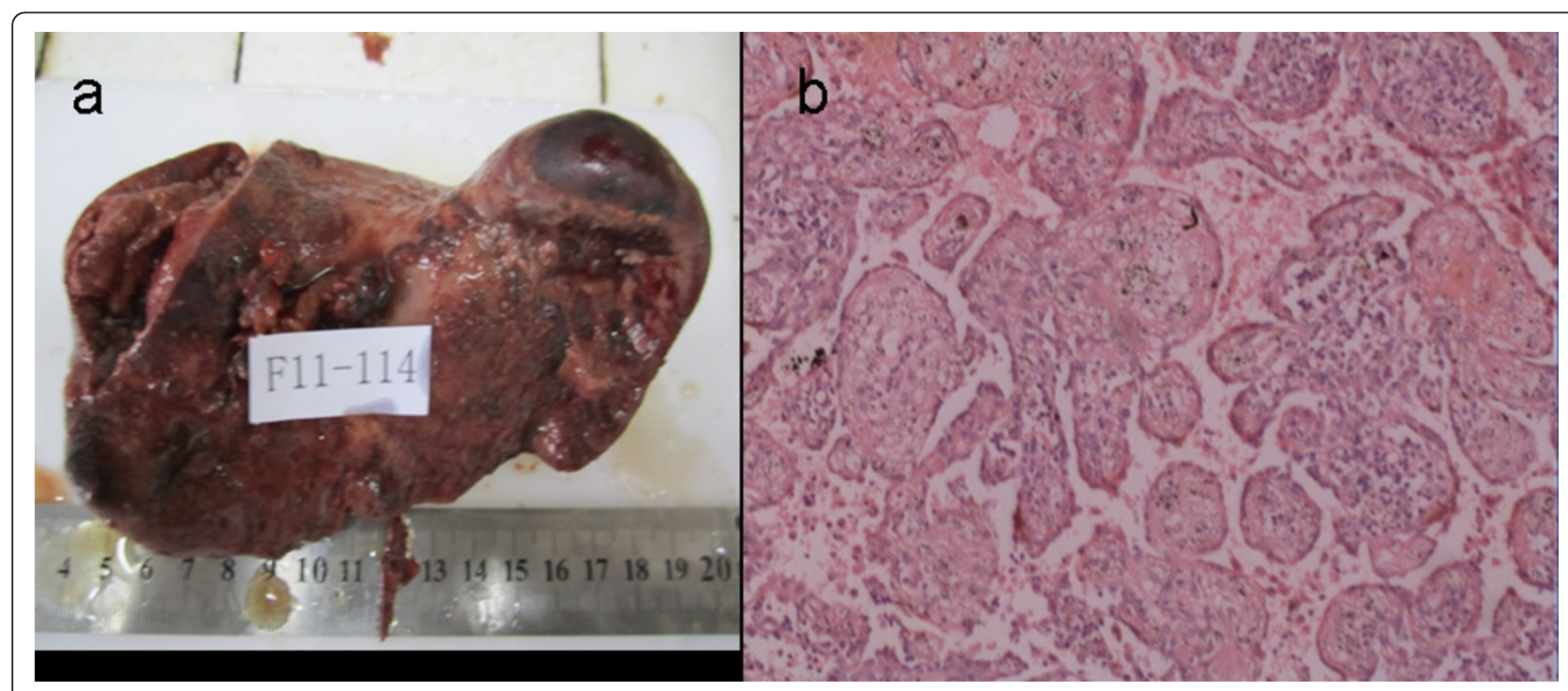

Figure 2 The spleen. Figure 2a:The spleen was $230.0 \mathrm{~g}$ in weight and $16.0 \times 10.0 \times 6.0 \mathrm{~cm}$ in dimension. Figure 2b: Higher-power view of the lesion demonstrates the characteristic histologic appearance of littoral cell angioma. The vascular spaces are lined with plump endothelial cells with the appearance of sinus lining, some of which have sloughed into the lumen (hematoxylin-eosin, original magnification 100x). 
neoplasm (angiosarcoma) [15]. Since the 1930s, endothelial cells lining the vascular sinuses of the spleen were considered as unique due to the exhibition of both phagocytic and hematopoietic properties [16]. Neoplasia of these cells results in the formation of LCA, which exhibits histological and molecular features consistent with both these epithelial and histiocytic cell types $[17,18]$.

The exact incidence of LCA is unknown although the incidence of splenic haemangioma varies from $0.03 \%$ to as high as $14 \%$ in a series of autopsy reports [19]. Clinically, most patients (> 55\%) are asymptomatic. The remaining patients with LCA present with splenomegaly, thrombocytopenia, anemia, or constitutional symptoms such as the fever of unknown origins [20]. The symptoms of anemia and thrombocytopenia may be hypersplenism-associated. Patients may also present with abdominal pain, or the tumor is diagnosed as an incidental finding [21].

Usually, the diagnosis is made after splenectomy for some other reasons. However, approximately $45 \%$ patients will present with splenomegaly, fever and features of hypersplenism (anaemia and thrombocytopenia) [22].

LCA may occur at any ages without sex-based predilection. Clinically, the disease may manifest as splenomegaly, anemia, and, less frequently, thrombocytopenia. LCA may also appear as a single or multiple lesions in the spleen. Diagnosis is usually made incidentally during surgery. Massive splenomegaly because of LCA can be mistaken as a pancreatic tumor.

Recent reports describe LCA as being associated with neoplasms of the colon, kidney, pancreas, lung and ovary $[23,24]$. Associations with leiomyosarcoma, melanoma and lymphoma have also been reported. In view of these findings, visceral neoplasm should be ruled out in all LCA patients.

\section{Conclusion}

As a result of its unique histological and immunohistochemical characteristics, the definitive diagnosis can only be made on tissue samples obtained either cytologically or post-splenectomy because radiological findings are not specific for LCA. Diagnosis can be made by fine-needle biopsy, but surgery seems crucial because of suspected malignancy. Therefore, an evaluation for concomitant malignancy and surveillance is recommended.

\section{Consent}

Written informed consent was obtained from the patient for publication of this Case report and any accompanying images. A copy of the written consent is available for review by the Editor-in-Chief of this journal.

\section{Author details}

'Department of Hepatic-Biliary-Pancreatic Diseases, Second Affiliated Hospital of Kunming Medical University, Kunming 650031, China. ${ }^{2}$ Molecular Epidemiology Joint Laboratory, Institute of Medical Biology, Chinese Academy of Medical Sciences, Kunming 650118, China. ${ }^{3}$ Ganmei Affiliated Hospital of Kunming Medical University, Kunming 650011, China.

\section{Authors' contributions}

$\mathrm{ZQH}$ performed the literature review and manuscript writing. YJA reviewed and revised the manuscript and provided radiographic images. QMS reviewed and revised the manuscript and provided pathological images. WL provided original idea and assisted the manuscript revision. All authors read and approved the final manuscript.

\section{Competing interests}

The authors declare that they have no competing interests.

Received: 20 September 2011 Accepted: 15 December 2011 Published: 15 December 2011

\section{References}

1. Chourmouzi D, Psoma E, Drevelegas A: Littoral cell angioma, a rare cause of long standing anaemia: a case report. Cases J 2009, 2:9115.

2. $\mathrm{Qu} Z \mathrm{ZB}$, Liu LX, Wu LF, Zhao S, Jiang HC: Multiple Littoral Cell Angioma of the Spleen: A Case Report and Review of the Literature. Onkologie 2007, 30:256-258.

3. Rana N, Ming Z, Hui MS, Bin Y: Case Report: Littoral cell angioma of spleen. Indian J Radiol Imaging 2009, 19:210-212.

4. Ben-Izhak O, Bejar J, Ben-Eliezer S, Vlodavsky E: Splenic littoral cell haemangioendothelioma: a new low-grade variant of malignant littoral celltumour. Histopathology 2001, 39:469-75.

5. Tee $M$, Vos $P$, Zetler $P$, Wiseman SM: Incidental littoral cell angioma of thespleen. World J Surg Oncol 2008, 6:87.

6. Falk S, Stutte H, Frizzera G: Littoral cell angioma. A novel splenicvascular lesion demonstrating histiocytic differentiation. Am J SurgPathol 1991, 15:1023-33.

7. Sauer J, Treichel U, Köhler HH, Schunk K, Junginger T: Littoral-cell angioma-a raredifferential diagnosis on splenic tumors. Dtsch Med Wochenschr 1999, 124:624-8.

8. Martel M, Cheuk W, Lombardi L, Lifschitz-Mercer B, Chan JK, Rosai J: Sclerosing angiomatoidnodular transformation (SANT): report of 25 cases of a distinctivebenign splenic lesion. Am J Surg Pathol 2004, 28:1268-79.

9. Schneider G, Uder M, Altmeyer K, Bonkhoff H, Gruber M, Kramann B: Littoral cell angioma of thespleen: CT and MRI imaging appearance. Eur Radiol 2000, 10:1395-400.

10. Hansen T, Habekost M, Flieger D, Kirkpatrick CJ: Littoral cell angioma of the spleen. Association with colon and hepatocellular carcinoma. Pathologe 2010, 31:290-292

11. Bisceglia M, Sickel JZ, Giangaspero F, Gomes V, Amini M, Michal M: Littoralcell angioma ofthe spleen: an additional report of four cases with emphasis on theassociation with visceral organ cancers. Tumori 1998, 84:595-9.

12. Levy DA, Abbott RM, Abbondanzo SL: Littoral cell angioma of thespleen: CT features with clinicopathologic comparison. Radiology 2004, 230:485-90.

13. Johnson C, Goyal M, Kim B, Wasdahl D, Nazinitsky K: Littoral cell angioma. Clin Imaging 2007, 31:27-31

14. Steensma DP, Morice WG: Littoral cell angioma associated with portalhypertension and resected colon cancer. Acta Hematol 2000, 104:131-4.

15. Pilz JB, Sperschneider T, Lutz T, Loosli B, Maurer CA: Littoral cell angioma in main and accessory intrapancreatic spleen presenting as splenic rupture. Am J Surg 2011, 201:e15-17.

16. Akyildiz H, Alper A, Soyuer I, Karahan OI, Sozuer E: Littoral cell angioma mimickingpancreatic tumor. Surg 2007, 141:690-1.

17. Oliver-Goldaracena JM, Blanco A, Mirakkes M, Martin-Gonzalez MA: Littoral cell angioma of the spleen: US and MR imaging findings. Abdom Imaging 1998, 23:636-9. 
18. Arber DA, Strickler JG, Chen YY, Weiss LM: Splenic vascular tumors: ahistologic, immunophenotypic, and virologic study. Am J Surg Pathol 1997, 21:827-35.

19. Halpert B, Gyorkey F: Lesions observed in accessory spleens of 311patients. Am J Clin Pathol 1959, 32:165-8.

20. Grantham M, Einstein D, McCarron K, Lichtin A, Vogt D: Littoral cell angioma of the spleen. Abdominal Imaging 1998, 23:633-635.

21. Gupta MK, Levin M, Aguilera NS, Pastores GM: Littoralcell angioma of the spleen in a patient with Gaucher disease. Am J Hematol 2001, 68(1):61-62.

22. Heese J, Bocklage T: Specimen fine-needle aspiration cytologyof littoral cell angioma with histologic and immunohistochemicalconfirmation. Diagnostic Cytopathol 2000, 22(1):39-44.

23. Kim HG, Park IS, Lee Jl, Jeong S, Lee JW, Kwon KS, Lee DH, Kim PS, Kim HG, Shin YW, Kim YS, Ahn IS, Lee KY: Littoral cell angioma (LCA) associated with liver cirrhosis. Yonsei Med J 2005, 46(1):184-188.

24. Harmon RJ, Cerruto CA, Scheckner A: Littoral cell angioma: a casereport and review. Curr Surg 2006, 63:345-50.

doi:10.1186/1477-7819-9-168

Cite this article as: Hu et al.: The splenic Littoral cell angioma in China: a case report and review. World Journal of Surgical Oncology 2011 9:168.

\section{Submit your next manuscript to BioMed Central} and take full advantage of:

- Convenient online submission

- Thorough peer review

- No space constraints or color figure charges

- Immediate publication on acceptance

- Inclusion in PubMed, CAS, Scopus and Google Scholar

- Research which is freely available for redistribution

Submit your manuscript at www.biomedcentral.com/submit 